\title{
PENDAMPINGAN KONSERVASI TANAH DENGAN RUMPUT AKAR WANGI DI GIRIWOYO WONOGIRI
}

\author{
Supriyadi 1) Sumani ${ }^{2)}$ Joko Winarno ${ }^{3)}$ Purwanto ${ }^{4)}$ dan Retno Rosariastuti ${ }^{5)}$ \\ Centre of Soil Quality for Sustainable Agriculture \\ Agriculture Faculty, Sebelas Maret University Surakarta Indonesia \\ supriyadi.tanah.fpuns@gmail.com, sumaniyulianto@yahoo.com, jokowien@staff.uns.ac.id, \\ purwahadi52@gmail.com, retnobs@yahoo.co.id
}

\begin{abstract}
Abstrak
Kegiatan ini dilaksanakan di Dukuh Ngulang, Desa Gedongrejo, Kecamatan Giriwoyo, Kabupaten Wonogiri dengan judul: Pendampingan Konservasi Tanah Dengan Rumput Akar Wangi Di Giriwoyo Wonogiri. Tujuan kegiatan ini antara lain merespon kebutuhan dan keinginan masyarakat untuk menyelamatkan tebing sungai dari ancaman banjir, longsor dan erosi tebing sungai Bengawan Solo Hulu, terciptanya model konservasi tanah dan air dengan penanaman rumput gelagah dan akar wangi yang didukung oleh masyarakat setempat. Metode yang digunakan yaitu pendampingan dan pemberdayaan masyarakat, Tim UNS sebagai fasilitator, sedangkan petani Dukuh Ngulang didorong untuk dapat mandiri. Selama proses kegiatan ini sebagian besar prakarsa diserahkan kepada petani yang ditunjuk sebagai koordinator lapang. Hasil yang dicapai antara lain luas demplot penanganan tebing sungai 200m x 2m, sedangkan di luar demplot sepanjang 200m (kanan dan kiri sungai). Kesimpulan dari kegiatan ini antara lain Kepala Desa Gedongrejo sangat mendukung adanya kegiatan IPTEKS dari Tim UNS, warga Dukuh Ngulang tempat demplot, merespon sangat positif dengan adanya pembuatan demplot penanganan tebing sungai, secara mandiri telah terbentuk Kelompok Pemerhati Tebing Sungai "Ngudi Mulyo" Dukuh Ngulang Gedongrejo Giriwoyo Wonogiri, warga petani Dukuh Ngulang mengharapkan Tim UNS tetap sebagai fasilitator dan mendamping sampai pembuatan bibit akar wangi.
\end{abstract}

Kata Kunci : bengawan solo, rumput gelagah, rumput akar wangi.

\section{PENDAHULUAN}

Berdasarkan hasil ekspedisi Kompas yang dilakukan di sungai Bengawan Solo pada bulan Juni 2008, dipertegas lagi bahwa manfaat keberadaan sungai Bengawan Solo bagi masyarakat sangat besar. Manfaat tersebut bukan saja untuk kebutuhan pertanian, tetapi juga untuk pemenuhan air minum, tenaga listrik dan kegiatan industri.

Sebagai wilayah tangkapan air yang terpanjang di pulau jawa ini, secara riil juga mengandung ancaman banjir yang cukup dahsyat seperti yang terjadi pada tanggal 26-28 Desember 2007. Akibat terjadinya hujan, maka mulai dari hulu sungai Bengawan Solo hingga hilir terjadi luapan air Bengawan solo.

Kejadian banjir di sepanjang sungai Bengawan Solo tersebut bukan saja disebabkan oleh mulai dangkalnya waduk Gajah Mungkur, tetapi disebabkan pula oleh telah semakin berkurangnya kawasan hijau di wilayah tangkapan air. Disamping itu, sejak pengisian waduk pada tanggal 29 Desember 1980, telah berlangsung pengisian sedimen secara cepat sehingga apabila tidak dilakukan penanggulangan maka fungsi waduk tersebut termasuk sebagai pengendali banjir akan segera menurun (JICA, 2007).

Menurut Sekretaris Dewan Sumber Daya Air Nasional (Anshori) yang mewakili Dirjen Sumber Daya Air Dep. PU pada saat membuka Lokakarya Pelatihan Pengelolaan Sumber Daya Air Terpadu (PSDAT) di Purwokerto (tanggal 28 Agustus 2008) disebutkan bahwa hingga saat itu pengelola sumber daya air masih terfragmentasi, hal ini mengakibatkan program sektoral yang terkait dengan pengelolaan sumber daya air tersebut sering kurang bersinergis. Masalah yang dihadapi salah satunya yaitu dalam pengelolaan sungai Bengawan Solo adalah laju erosi Lingkungan Hidup dan Bencana

603 
dan degradasi hutan serta lahan yang lebih besar dari pada laju rehabilitasi. Perubahan peruntukan lahan pada daerah tangkapan hujan ditandai dengan semakin meluasnya areal pertanian, perkebunan dan permukiman.

Kemudian siapakah yang harus bertanggungjawab terhadap keadaan ini. Tentunya kita tidak dapat begitu saja menyalahkan pihak-pihak tertentu. Oleh karenanya, yang paling penting adalah kesadaran kita bersama dalam upaya melestarikan potensi sungai Bengawan Solo. Tanpa adanya motivasi bersama dalam memelihara dan pemanfaatan kawasan tersebut, maka dampak yang jauh merugikan dimasa mendatang yang disebabkan oleh kejadian erosi dan banjir tidak menutup kemungkinan dapat lebih serius.

Secara nyata sebenarnya keprihatinan kerusakan lahan sungai Bengawan Solo, khususnya di bagian hulu sangat dirasakan pula oleh masyarakat. Terbukti ketika Tim melakukan survei awal pasca terjadinya banjir, maka terungkaplah harapan-harapan yang diinginkan oleh masyarakat tersebut seperti: upaya penanggulangan longsor tebing sungai yang sangat meresahkan.

Berdasarkan pengakuan dan harapan masyarakat tersebut, maka dalam kegiatan ini dilakukan gerakan penanaman rumput gelagah dan akar wangi yang diawali dari lahan di sekitar Dukuh Ngulang, Desa Gedongrejo, Kabupaten Wonogiri. Alasan penentuan lokasi ini didasarkan dari adanya kesadaran dan motivasi masyarakat setempat yang memiliki keinginan besar untuk mempertahankan tebing sungai agar tidak longsor. Kegiatan ini diharapkan dapat menjadi pemicu dan penggerak bagi masyarakat setempat untuk secara konsisten melakukan rehabilitasi tebing sungai.

\section{METODE}

\section{Tempat dan Waktu}

Kegiatan IPTEKS ini dilaksanakan di Dukuh Ngulang, Desa Gedongrejo, Kecamatan Giriwoyo, Kabupaten Wonogiri Jawa Tengah pada Bulan April - November 2019.

\section{Pelaksanaan Kegiatan}

Dalam kegiatan penerapan IPTEKS ini dilakukan dengan metode kemandirian, sedangkan Tim UNS sebagai fasilitator. Adapun pelaksanaannyan dapat dibedakan menjadi beberapa tahap antara lain observasi lapang, perencanaan desain dan lokasi demplot, survei ketersediaan bibit akar wangi, diskusi terbatas dengan petani, penyiapan demplot, diskusi dan evaluasi penyiapan demplot, pembentukan kelompok pemerhati tebing sungai, monitoring hasil penyiapan demplot, kunjungan ke pengrajin akar wangi, sekolah lapang budidaya akar wangi, penanaman rumput akar wangi, monitoring hasil penanaman rumput gelagah dan akar wangi, perencanaan tindak lanjut ke depan.

\section{HASIL DAN PEMBAHASAN}

\section{Observasi Lapang}

Observasi lapang ini, sasaran informan yang dituju yaitu Ketua Dukuh Ngulang (Pak Tugiman). Dari hasil wawancara ini diperoleh dua hal pokok yang saat ini sangat diperlukan oleh petani antara lain yaitu pencegahan meluasnya pengikisan dan atau longsor tebing sungai yang diakibatkan oleh adanya banjir maupun akibat dari adanya penggalian pasir liar, pencegahan meluasnya penambangan pasir liar yang dilakukan di dasar sungai oleh masyarakat dari lain desa (Gambar 1). Kekhawatiran ini terutama dirasakan oleh petani pemilik lahan yang tepat berada di tepi sungai.

Adapun dasar pertimbangan utama pelibatan Pak Tugiman dalam kegiatan ini yang dimulai dari proses: identifikasi kebutuhan dan keinginan, mengkoordinasikan dengan petani sampai dengan kegiatan evaluasi dan monitoring adalah untuk mengarahkan kepada petani bahwa segala sesuatu yang dikerjakan dan diupayakan dalam program ini merupakan kebutuhan petani sendiri (Sutopo, H.B., 2006: 38).

Dalam diskusi antara Pak Tugiman dengan Tim UNS, Pak Tugiman menyatakan setuju sekali, jika Tim UNS melakukan pendampingan kegiatan untuk mencegah meluasnya kerusakan tebing sungai. Pada saat itu, Tim UNS menawarkan solusi dalam pencegahan meluasnya kerusakan tebing sungai yaitu dengan penanaman: rumput gelagah, rumput akar wangi dan ditumpangsari dengan rumput gajah. Pertimbangan ini diberikan dengan dasar:

a. Rumput gajah, mampu melindungi hempasan air ketikan terjadi banjir. Tepatnya, ketika terjadi banjir, maka rumput gajah ini akan

$$
\text { Lingkungan Hidup dan Bencana }
$$


rebah dan seolah-olah menjadi pelindung dasar sungai maupun tebing.

b. Rumput akar wangi, jenis rumput ini memiliki akar yang berkembang secara horizontal dan memanjang dengan panjang akar dari $40 \mathrm{~cm}$ hingga $60 \mathrm{~cm}$, sehingga diharapkan dapat atau mampu menahan kekuatan air dalam mengikis permukaan tanah. Disamping itu, manfaat akar wangi ini jika ditanam pada lahan yang sengaja untuk usaha ekonomi, maka akan memiliki nilai ekonomi lebih tinggi jika dibandingkan dengan tanaman yang selama ini ditanam oleh petani seperti: ketela pohon dan sayuran sebagai tanaman sela.

c. Rumput gajah, ditawarkan kepada petani sebagai tanaman sela diantara tanaman akar wangi terutama untuk kebutuhan pakan ternak. Namun demikian, menurut Pak Tugiman dalam desain ini, rumput gajah perlu dihindarkan sebab dikawatirkan justru mengundang orang untuk melakukan pencurian.

\section{Perencanaan Desain dan Lokasi Demplot}

Kegiatan ini diawali dengan pembicaraan tentang desain dan penentuan demplot penanganan tebing sungai. Pembicaraan terlebih dahulu dilakukan di rumah Pak Tugiman, yang telah ditunjuk oleh Tim UNS sebagai koordinator lapang dalam pelaksanaan kegiatan ini. Lokasi demplot penanganan tebing sungai ini difokuskan di lahan milik Pak Tugiman. Pertimbangan utama pemilihan lokasi demplot antara lain mengurangi resiko konflik kepentingan prioritas peruntukan lahan, secara kebetulan lahan milik Pak Tugiman terletak tepat di bagian kanan dan kiri memanjang sungai dengan panjang \pm 200 meter dan lebarnya \pm 4 meter, agar para petani di dukunh Ngulang dapat melihat dan menilai kemanfaatan kedua macam jenis rumput tersebut untuk penguat tebing sungai (Gambar 2).

Setelah terjadi kesepakatan bulat antara Pak Tugiman dengan Tim UNS, dilanjutkan bertemu dengan Kepala Desa Gedongrejo (Pak Suyatno) di rumahnya. Dalam pertemuan ini, secara langsung Pak Lurah mengucapkan rasa syukur dan terima kasih yang sangat mendalam karena Tim UNS telah bersedia memprakarsai dan memfasilitasi masyarakat khususnya di Dukuh Ngulang untuk secara bersama-sama melindungi tebing sungai dari ancaman kerusakan yang disebabkan oleh kejadian alami (banjir) maupun oleh kegiatan manusia yang kurang bertanggungjawab dan dengan adanya kegiatan ini Kepala Desa Gedongrejo menaruh harapan yang besar khususnya dalam kaitannya dengan upaya mengurangi resiko kerusakan tebing sungai. Makna yang dapat diperoleh Tim UNS yaitu adanya harapan menyadarkan para warga yang selama ini melakukan penambangan pasir secara liar yang secara nyata berakibat kerusakan tebing sungai.

\section{Survei Ketersediaan Bibit Akar Wangi}

Survei ketersediaan bibit akar wangi ke lokasi sentra rumput akar wangi yaitu di dusun Kepek, Semin Wonosari. Pada kesempatan ini telah terjadi kesepakatan harga bibit rumput akar wangi yaitu dengan harga Rp. 2.500,- /kg. Adapun untuk sementara Tim membeli bibit akar wangi $500 \mathrm{~kg}$, yang diharapkan dapat ditaman pada demplot $(200 \mathrm{~m}$ $\mathrm{x} 4 \mathrm{~m}$ ) dan kelebihannya ditaman di bagian tebing lainnya (Gambar 3).

\section{Diskusi Terbatas Dengan Petani}

Dalam pelaksanaan sosialisasi desain penanaman rumput gelagah dan akar wangi dilakukan di rumah Pak Tugiman. Pada acara ini yang bertindak sebagai fasilitator yaitu Pak Tugiman (sebagai koordinator lapang) dan dibantu oleh 2 (dua) mahasiswa Fakultas Pertanian UNS. Secara materi, pengetahuan desain penanganan tebing sungai antara Pak Tugiman dan mahasiswa sudah satu ide, sebab sebelumnya telah dilakukan pembekalan terhadap kedua mahasiswa tersebut.

Tujuan utama dilakukannya diskusi terbatas dengan petani yaitu agar diperoleh kesamaan persepsi dan arah pengembangan ke depan. Hal ini perlu mendapat penekanan khusus sebab adanya perbedaan yang cukup mendasar antara metode penanaman yang dilakukan oleh Pak Daryanto (pengusaha akar wangi) Tim UNS. Pak Daryanto sebagai pengusaha akar wangi menanamnya dilakukan di atas bedengan (guludan), sedangkan Tim UNS dengan cara melubangi tanah secara langsung. Perbedaan prinsip ini terjadi karena perbedaan fungsi dari penanaman akar wangi tersebut (Gambar 4).

Materi yang dibicarakan dalam diskusi ini yaitu terkait dengan metode perlindungan tebing

$$
\text { Lingkungan Hidup dan Bencana }
$$


sungai dari ancaman terjadinya kerusakan yang diakibatkan oleh pengikisan air sungai, manfaat rumput akar wangi sebagai pelindung tanah dan untuk kebutuhan usaha yang berorientasi ekonomi, tugas dan tanggungjawab Tim UNS maupun petani dalam kaitannya dengan kegiatan IPTEKS ini, prospek kedepan dengan keberhasilan program IPTEKS ini.

\section{Penyiapan Demplot}

Para petani ini, selanjutnya juga akan menanam rumput akar wangi di lahannya masingmasing. Dalam penyiapan lahan ini, secara khusus difokuskan pada demplot, sedangkan untuk pengembangannya akan dilakukan pada saat setelah kunjungan lapang di pengrajin maupun di petani akar wangi. Kegiatan penyiapan lahan rumput gelagah maupun akar wangi (Gambar 5).

\section{Diskusi dan Evaluasi Demplot}

Materi utama dalam diskusi ini, tidak jauh berbeda dengan yang telah dilakukan pada malam sebelumnya. Pembicaraan teknis atau desain pola tanam tidak berlanjut sebab masing-masing petani telah memahami prioritas yang diutamakan dalam program ini yaitu pencegahan terjadinya kerusakan tebing sungai. Pembicaraan yang cukup serius yaitu tindak lanjut dengan kegiatan ini. Diantaranya yang menarik minat para petani yaitu melihat dan mengetahui secara langsung cara budidaya rumput akar wangi, melihat dan mengetahui pembuatan kerajinan dengan akar wangi, mengetahui dan ingin kenal secara langsung calon pembeli akar wangi, pembicaraan perwakilan dari petani yang akan mengikuti kunjungan ke Yogya, pembentukan Kelompok Pemerhati Tebing Sungai dan yang terakhir yaitu mengharapkan adanya bantuan ternak bagi warga yang nantinya akan dijalankan secara bergulir.

\section{Pembentukan Kelompok Pemerhati Tebing Sungai}

Berdasarkan hasil musyawarah mufakat dan berjalan sangat demokratis, maka petani yang hadir pada acara diskusi telah memutuskan untuk membentuk kelompok pemerhati tebing sungai bengawan solo hulu yang diberi nama "Kelompok Pemerhati Tebing Sungai Ngudi Mulyo" yang diketuai oleh Pak Tugiman dengan penanggungjawab Pak Widodo (Sekretaris Desa
Kedungrejo) dan Pak Suyatno (Kepala Desa Kedung Rejo) sebagai pelindung.

Setelah pembentukan kelompok terdapat beberapa rencana kerja antara lain pertemuan rutin anggota yang waktunya akan dibahas lagi, Penanaman rumput gelagah dan akar wangi di lokasi demplot serta di sebagian lokasi lahan milih anggota, khususnya dalam kegiatan ini diprioritaskan untuk pemeliharaan tebing sungai, sehingga ditanam sepanjang tebing sungai, Pertemuan terjadwal dengan Tim UNS sebagai pihak fasilitator yang waktunya menyesuaikan dengan kegiatan TIM UNS, Monitoring respon para anggota dalam kaitannya dengan penerapan rumput gelagah dan akar wangi sebagai upaya penguat tebing sungai, Indentifikasi permasalahan baru yang muncul setelah adanya kegiatan program pembuatan demplot penanganan tebing sungai, Identifikasi dan dokumentasi potensi pengembangan yang mungkin dilakukan secara mandiri oleh anggota Kelompok Pemerhati Sungai maupun dengan Tim UNS.

\section{Monitoring Hasil Penyiapan Demplot}

Tim UNS beserta Pak Tugiman meninjau hasil kerja pada anggota Kelompok Pemerhati Tebing Sungai dalam menyiapkan demplot untuk tanaman gelagah dan rumput akar wangi. Pada saat itu, telah terjadi kesepakatan bersama antar anggota yaitu dalam penyiapan demplot ini sambil menanam rumput gelagah. Keputusan ini disepakati, sebab bibit rumput gelagah telah banyak tersedia di lokasi, sehingga tinggal memindahkan pada lubang-lubang yang telah dibuat (Gambar 5).

\section{Kunjungan Ke Pengrajinan Akar Wangi}

Tim UNS mengantarkan perwakilan dari anggota Pemerhati Tebing Sungai untuk melihat secara langsung lokasi budidaya akar wangi dan tempat gerai kerajinan akar wangi. Tujuan pertama yaitu di lokasi sekitar gumup pasir wilayah Parang Tritis, tetapi ketika sampai di tujuan, hamparan rumput akar wanginya telah tidak ada. Kemungkinan besar akar wanginya telah dipanen.

Perjalanan selanjutnya yaitu menuju ke Sentolo, tepatnya di Kurnia Handicraf yang diterima oleh Butujiyanto. Di lokasi ini, petani diberikan penjelasan tentang berbagai manfaat rumput akar wangi khususnya dalam bentuk berbagai macam kerajinan. Dijelaskan pula, bahwa Kurnia Handicraf

$$
\text { Lingkungan Hidup dan Bencana }
$$


ini juga sanggup untuk menampung hasil akar wangi dari petani Dukuh Ngulang ini (Gambar 6).

\section{Sekolah Lapang Budidaya Akar Wangi}

Tim UNS mengantarkan perwakilan anggota Kelompok Pemerhati Tebing Sungai untuk memperoleh penjelasan berbagai hal yang terkait dengan budidaya tanaman rumput akar wangi di wilayah sentra akar wangi. Tujuan utama kegiatan ini antara lain memberikan pencerahan kepada petani tentang manfaat akar wangi dan prospeknya kedepan baik ditinjau sebagai alat pencegahan kerusakan tebing sungai maupun untuk orientasi ekonomi, memberikan pengetahuan secara langsung di lapang bagaimana teknik budidaya tanaman akar wangi, mulai dari membuat atau menyiapkan bibit, penyiapan lahan, penanaman, pemberian pupuk dasar, perawatan tanaman, teknik pencabutan tanaman hingga penanganan pasca panen dan pemasarannya yang dipandu oleh ahlinya (Pak Daryanto).

Tujuan lain kegiatan ini yaitu mengarahkan kepada petani untuk melakukan perbandingan tentang jenis tanaman yang cocok untuk tujuan pengawetan tebing sungai maupun untuk kepentingan meningkatkan pendapatan, Memfasilitasi petani untuk nantinya dapat meningkatkan jejaring usaha yang dapat bermanfaat bagi peningkatan pendapatan mereka, mengetahui secara langsung tempat pemesanan atau pembelian bibit akar wangi yang nantinya akan ditanam petani dan sekaligus memberikan kesempatan kepada petani untuk berdialog dengan calon penampung hasil akar wangi.

\section{Penanaman Rumput Akar Wangi}

Dalam penanaman rumput gelagah maupun rumput akar wangi telah dilakukan sendiri oleh para petani yang tergabung dalam kegiatan pembuatan demplot ini. Adapun metode yang diterapkan di demplot sesuai dengan yang telah didiskusikan pada saat pelaksanaan sosialisasi. Khususnya dalam kaitannya dengan penanaman akar wangi di demplot tidak sama dengan teknik yang diberikan oleh Pak Daryanto. Perbedaannya terletak pada terknik dan media tanamnya. Jika di sentra akar wangi (di desa Kepek, Semin Wonosari, Gunungkidul) tanaman akar wangi ditanam di atas bedengan (guludan), maka di lokasi demplot lubang tanaman akar wangi tidak di atas bedengan, tetapi pada tanah tersebut langsung dibuat lubang.

Perbedaannya cukup mendasar, terutama pada kemanfaatan tujuan akhir. Jika di Kepek sepenuhnya untuk tujuan komersial, maka di demplot (dukuh Ngulang) tanaman akar wangi diperuntukkan sebagai penguat tebing sungai, sehingga diupayakan usikan terhadap media tanam sesedikit mungkin. Adapun pada lokasi khusus yang diperuntukkan sebagai calon bibit akar wangi di masa mendatang, maka penanamannya di atas bedeng atau tanahnya sedikit dibuat semacam guludan. Perbedaan teknik penanaman ini telah ditanyakan petani kepada Tim UNS dan setelah mendapatkan penjelasan yang cukup, terutama karena adanya perbedaan tujuan tersebut, maka petani dapat menerima dengan perasaan puas. Dari jumlah bibit yang dipesan oleh Tim UNS (750 kg) oleh petani Dukuh Ngulang dapat ditanam pada demplot (200 m x $2 \mathrm{~m}$ ) dan sebagian satu lajur memamjang di tepi tebing sungai sepanjang 200 meter kanan dan kiri sungai. Menurut rencana pada tindak lanjut, petani Dukuh Ngulang telah meminta Tim UNS untuk menambah bibit sejumlah $250 \mathrm{~kg}$ yang akan dipergunakan untuk menambah jumlah larikan tanaman rumput akar wangi.

\section{Monitoring Hasil Penanaman Rumput Gelagah dan Akar Wangi}

Setelah Tim UNS mendapat laporan dari Pak Tugiman bahwa bibit akar wangi telah ditanam, maka Tim UNS menugaskan kepada 2 (dua) mahasiswa Fak. Pertanian (Endro dan Dinar) untuk melakukan monitoring. Hasil dari monitoring ini, semua bibit yang telah dikirim oleh Pak Daryanto telah ditanam oleh petani, baik di demplot maupun di tempat khusus yang direncanakan untuk pengembangan bibit akar wangi.

Adapun kondisi rumput gelagah dan akar wangi, pada saat ini masih belum tampak ada perkembangan, sebab baru saja di tanam. Monitoring dilakukan tentang kondisi tanaman dan melakukan evaluasi bersama dengan koordinator lapang (Pak Tugiman). Berikut ini disajikan foto-foto hasil penanaman akar wangi baik di demplot maupun di lokasi pengembangan bibit.

$$
\text { Lingkungan Hidup dan Bencana }
$$




\section{Perencanaan Tindak Lanjut ke Depan}

Kegiatan monitoring awal yang telah dilakukan, terutama untuk melihat apakah tanaman gelagah maupun akar wangi telah ditananam sesuai dengan tujuan konservasi tebing sungai atau berbeda dengan tujuan awal. Materi yang dievaluasi yaitu terkait dengan kondisi tanaman gelagah dan akar wangi. Koordinasi dengan koordinator lapang (Pak Tugiman) terkait dengan perawatan pemeliharaan tanaman gelagah dan akar wangi, pelaksanaan pemupukan yang perlu dilakukan dengan pupuk yang telah disiapkan yaitu: pupuk kandang, urea, SP3 dan $\mathrm{KCl}$, sesuai dengan waktu yang telah ditentukan, penyulaman pada tanaman yang mati, dengan menggunakan cadangan bibit yang telah disiapkan, pemangkasan daun akar wangi, pemanenan akar wangi, khususnya yang ditanam pada lokasi yang diperuntukkan untuk pembuatan bibit dan kebutuhan komersial, melakukan pendampingan dalam menjalin kerja sama dengan penampung hasil akar wangi yaitu Pak Daryanto.

\section{Kesimpulan}

Kesimpulan kegiatan ini antara lain Kepala Desa Gedongrejo, Kecamatan Giriwoyo sangat berterima kasih kepada Tim UNS dengan adanya kegiatan ini. Terutama sekali kegiatan ini dapat memberikan contoh teknologi penanganan tebing sungai dan menunjukkan kepada para penambang pasir bahwa warga Dukuh Ngulang dengan serius berusaha menjaga kerusakan tebing sungai, warga petani Dukuh Ngulang sangat merespon positif dengan adanya kegiatan dari Tim UNS ini, secara spontan petani yang terlibat dalam kegiatan pembuatan demplot ini membentuk organisasi dengan nama Kelompok Pemerhati Tebing Sungai "Ngudi Mulyo" Dukuh Ngulang Gedongrejo Giriwoyo Wonogiri, Warga petani Dukuh Ngulang sangat mengharapkan kepada Tim UNS agar kegiatan ini didampingi hingga masa pembuatan bibit akar wangi.

\section{REFERENSI}

Anonim. 2007. Perlu Dilakukan Pengelolaan Sumber Daya Air Terpadu. http://www.jasatirta1.go.id/berita.php?subacti on $=$ showfull $\& i d=1220240203 \&$ archive $=\&$ sta rt_from $=\& u$ cat $=6 \&$. copyright 2007 JASA TIRTA I. Diunduh pada tanggal 3 September 2008

JICA. 2007. Studi Penanganan Sedimentasi Waduk Serbaguna Wonogiri. Laporan Akhir Sementara. Volume II. Nippon Koei and Yachiyo Engineering Co. Ltd.

Mikkelsen, Brita. 2003. Metode Penelitian Partisipatoria Dan Upaya-Upaya Pemberdayaan. Sebuah Buku Pegangan Bagi Para Praktisi Lapangan. Yayasan Obor Indonesia. Jakarta.

Sutopo, H.B. 2006. Penelitian Kualitatif. Dasar Teori dan Terapannya Dalam Penelitian. Universitas Sebelas Maret. Surakarta. 


\section{LAMPIRAN}

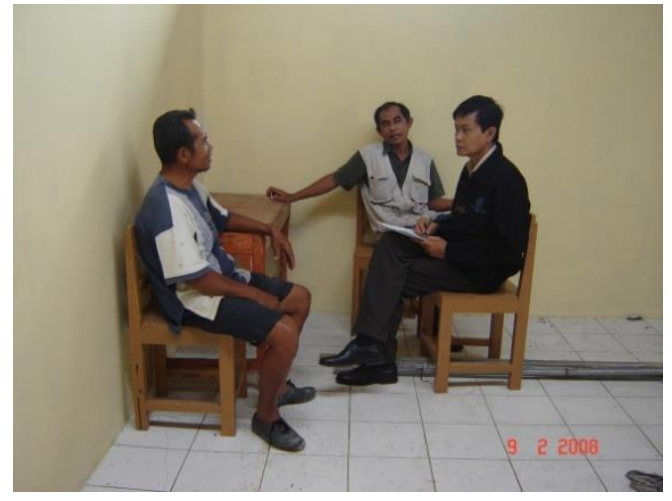

\section{Gambar 1}

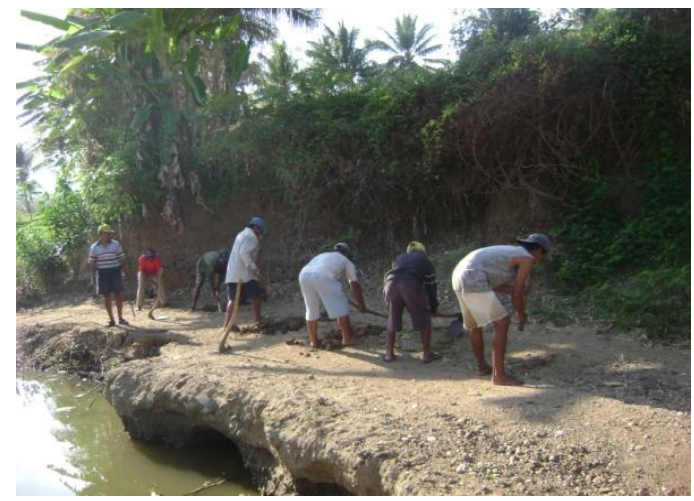

Gambar 3

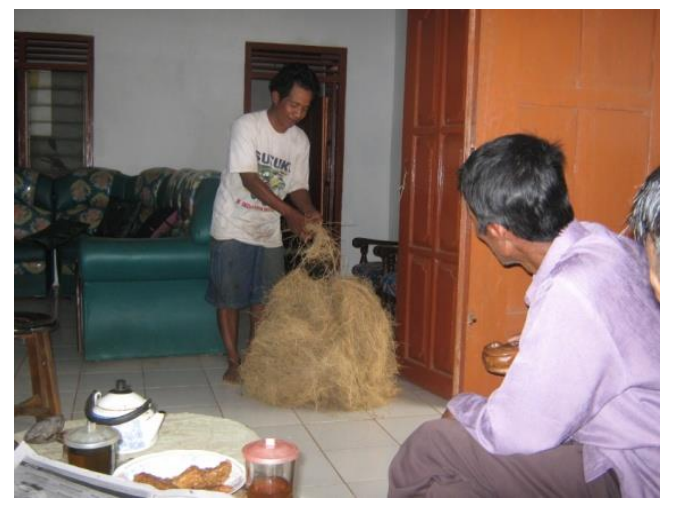

Gambar 5

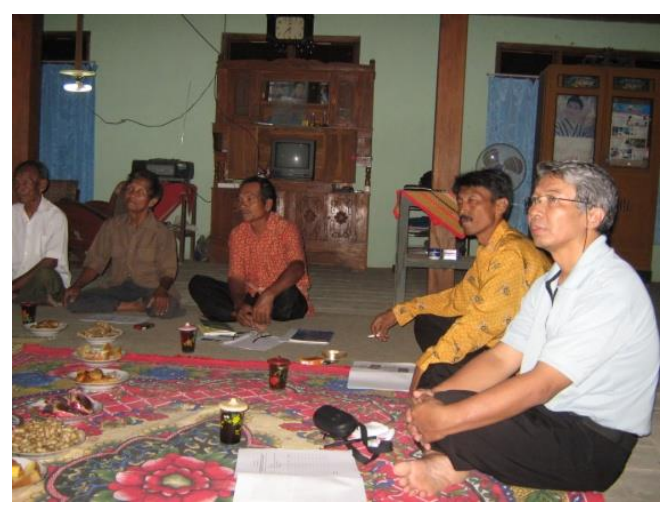

Gambar 2

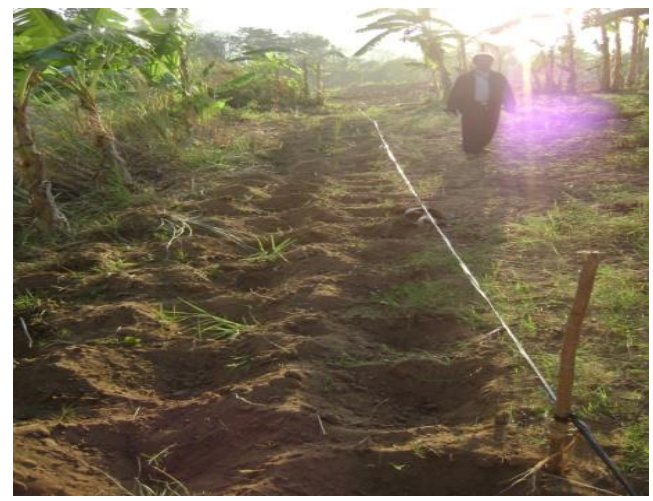

Gambar 4

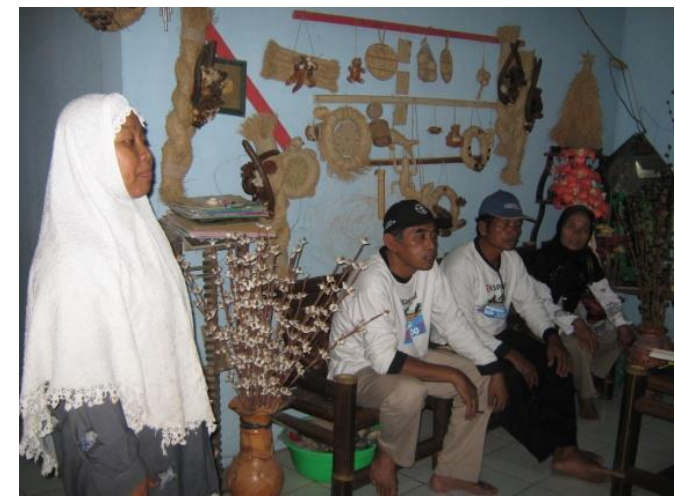

Gambar 6 